\title{
Holocene climate changes in southern Greenland: evidence from lake sediments
}

\author{
CAMILLA S. ANDRESEN, ${ }^{1}$ SVANTE BJÖRCK, ${ }^{1}$ OLE BENNIKE ${ }^{2}$ and GERARD BOND ${ }^{3}$ \\ 1 GeoBiosphere Science Centre, Department of Geology, Quaternary Geology, University of Lund, Lund, Sweden \\ 2 Geological Survey of Denmark and Greenland, Copenhagen, Denmark \\ 3 Lamont-Doherty Earth Observatory of Columbia University, Palisades, NY, USA
}

Andresen, C. S., Björck, S., Bennike, O. and Bond, G. 2004. Holocene climate changes in southern Greenland: evidence from lake sediments. J. Quaternary Sci., Vol. 19 pp. 783-795. ISSN 0267-8179.

Received 10 October 2003; Revised 25 June 2004; Accepted 13 July 2004

\begin{abstract}
A Holocene lake sediment record is presented from Lake N14 situated on Angissoq Island $15 \mathrm{~km}$ off the main coast of southern Greenland. The palaeoclimatic development has been interpreted on the basis of flux and percentage content of biogenic silica, clastic material, organic material and sulphur as well as sedimentation rate, moss content and magnetic susceptibility. A total of 43 radiocarbon dates has ensured a reliable chronology. It is argued that varying sediment composition mainly reflects changing precipitation. By analogy with the present meteorological conditions in southern Greenland, Holocene climate development is inferred. Between 11550 and $9300 \mathrm{cal} . \mathrm{yr}$ BP temperature and precipitation increase markedly, but this period is climatically unstable. From 9300 yr BP conditions become more stable and a Holocene climatic optimum, characterised by warm and humid conditions, is observed from 8000 to $5000 \mathrm{cal}$.yr BP. From $4700 \mathrm{cal}$. yr BP the first signs of a climatic deterioration are observed, and from $3700 \mathrm{cal}$. yr BP the climate has become more dry and cold. Superimposed on the climatic long-term trend is climate variability on a centennial time-scale that increases in amplitude after $3700 \mathrm{cal}$. yr BP. A climatic scenario related to the strength and position of the Greenland high-pressure cell and the Iceland low-pressure cell is proposed to explain the Holocene centennial climate variability. A comparison of the Lake N14 record with a terrestrial as well as a marine record from the eastern North Atlantic Ocean suggests that the centennial climate variability was uniform over large areas at certain times. Copyright (C) 2004 John Wiley \& Sons, Ltd.
\end{abstract}

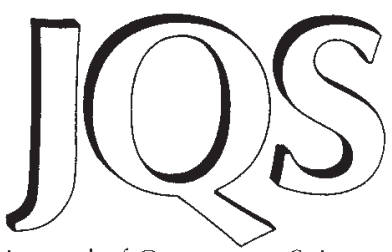

Journal of Quaternary Science

KEYWORDS: paleolimnology; paleoclimate; centennial and millennial variability; biogenic silica; mosses; Neoglaciation; Holocene; southern Greenland.

\section{Introduction}

During recent years focus has increased on investigations of climate variability during the current interglacial period. One important aspect is the understanding of the yet sparsely known mechanisms behind climate changes on centennial and millennial timescales. The North Atlantic is an important study region for Holocene climatic variability because of the presence of the Polar Frontal systems and the oceanographic setting influenced by North Atlantic Deep Water formation. In particular southern Greenland provides opportunities for recording even minor fluctuations in the position of the Polar Frontal system, but as yet the number of high-resolution palaeoclimatic studies from the area is sparse (Fredskild, 1973; Funder and Fredskild, 1989; Kaplan et al., 2002; Björck et al., 2002; Lassen et al., 2004). This paper presents and discusses data from a lacustrine sediment core from the southernmost tip of Greenland. High

* Correspondence to: Camilla Snowman Andresen, GeoBiosphere Science Centre, Quaternary Sciences, Lund University, Solvegaten 12, SE-22362 Lund, Sweden. E-mail: Camilla.Andresen@geol.lu.se deposition rate along with very dense radiocarbon dating allow multi-decadal time-scale resolution, thereby making it possible to set up a reliable chronology for the Holocene climatic history of this particular region.

\section{Setting}

Modern oceanography and climate conditions

The modern surface oceanography in the area south of Greenland is characterised by cold, low salinity, polar waters of the East Greenland Current (EGC), which flows southwards along the east coast of Greenland (Fig. 1A). The EGC carries icebergs and multi-year pack ice from the Arctic Ocean as well as sea ice formed in situ in East Greenland fjords. Along the southeast coast of Greenland the EGC mixes with the Irminger Current - a branch of the warm and saline Atlantic Current that moves southwestwards - and the EGC continues as a flow of mixed water around Cape Farewell and partially up the west coast where the ice quickly melts. The wide transitional zone 

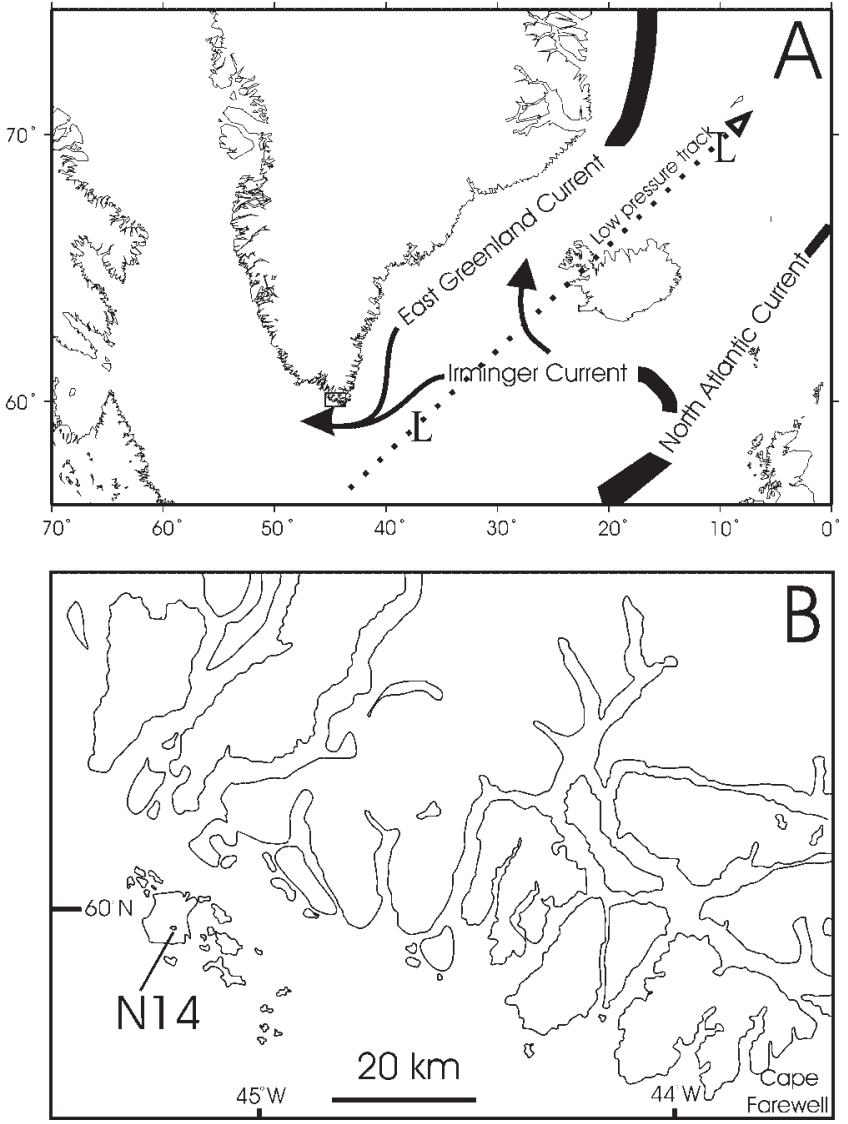

Figure $1 \mathrm{~A}$, main surface currents in the North Atlantic Ocean. Stippled line denotes the direction of low pressure storm tracks. Approximate position of the Icelandic low and the Barents low are denoted L. B, location map of Angissoq Island and lake N14

in the Denmark Strait between the polar waters and the Atlantic waters is defined as the oceanographic Polar Front (Dietrich et al., 1980), which varies markedly on annual, interannual, and even longer time scales (Malmberg, 1970; Sigtryggson, 1972).

Climate in southern Greenland is low-arctic oceanic and winter weather is highly influenced by the Icelandic low, which travels as low pressure systems crossing south Greenland from the southwest to the northeast. This results in alternation between eastern winds with rising temperature and increased precipitation and northwesterly winds with clear and colder weather. However, the wind directions may differ locally due to topography.

During the last five decades the climate in southern Greenland has been shown to be highly related to the North Atlantic Oscillation (Hanna and Cappelen, 2003). The North Atlantic Oscillation is an index of monthly winter air-pressure differences between Iceland and the Azores - a high difference corresponds to a positive index of the North Atlantic Oscillation and a low difference corresponds to a negative index (Hurrell, 1995). During times of a stationary low pressure area to the south of Greenland (negative index of the North Atlantic Oscillation) climate in southern Greenland is warm. At the same time winters in northwestern Europe are frequently influenced by cold and dry northeasterly winds. In contrast, during times of a stationary low pressure area near Iceland (positive index of the North Atlantic Oscillation) the climate in southern Greenland becomes colder (Cappelen et al., 2001), whereas winter conditions in northwestern Europe are relatively warm and moist due to increased strength of the westerlies.

At the meteorological station in Qaqortoq $\left(60^{\circ} 43^{\prime} \mathrm{N}\right.$, $46^{\circ} 03^{\prime} \mathrm{W}$ ), positioned on the outer west coast around $80 \mathrm{~km}$ from the studied site, the mean annual temperature is $0.6^{\circ} \mathrm{C}$. Mean summer (June-August) temperature is $6.5^{\circ} \mathrm{C}$ and mean winter (December-February) temperature is $-5^{\circ} \mathrm{C}$, but temperatures of $22^{\circ} \mathrm{C}$ and $-30^{\circ} \mathrm{C}$ have been measured. The mean annual number of days with frost is 213.3 with a frost-free period in July-August. Local annual precipitation is $858 \mathrm{~mm}$, but may reach values of $2000-3000 \mathrm{~mm}$ in the Cape Farewell area, suggesting that precipitation could have varied between 1000 and $2000 \mathrm{~mm}$ at the study site. The area is rather windy with a mean wind speed of $3.8 \mathrm{~m} / \mathrm{s}$ and a maximum wind speed of $41.2 \mathrm{~m} / \mathrm{s}$ and the number of days with strong breeze (windspeed $\geq 10.8 \mathrm{~m} / \mathrm{s}$ ) is 81.3 per year. All meteorological measurements were recorded during the period 1961-1990 (Cappelen et al., 2001).

\section{Site description}

The investigated lake - unofficially named N14 - is situated on Angissoq Island $\left(59^{\circ} 58.99^{\prime} \mathrm{N}, 44^{\circ} 10.81^{\prime} \mathrm{W}\right)$, which is located around $15 \mathrm{~km}$ from the main coast of south Greenland (Fig. 1A,B). The island has a diameter of around $6 \mathrm{~km}$, its highest point reaches $101 \mathrm{~m}$ a.s.l. and it is devoid of glaciers/perennial snow fields. The area was deglaciated before 14100 calendar years ago (Bennike and Björck, 2002). The lake was isolated from the ocean due to isostatic uplift 13800 calendar years ago (Bennike and Björck, 2000; Bennike et al., 2002) and is today situated $33 \mathrm{~m}$ a.s.l. The roundish lake has a diameter of around $200 \mathrm{~m}$ and a water depth of $3.3 \mathrm{~m}$ at the coring site in the middle of the lake. The surrounding bedrock is granodioritic gneiss, heavily ice-scoured during glaciations, and unconsolidated Quaternary deposits are sparse. The vegetation is dominated by low Empetrum nigrum heaths. The pre-Holocene history of the lake has been described by Björck et al. (2002).

\section{Methods}

\section{Field and laboratory work}

Eight $1 \mathrm{~m}$ long cores were sampled from the ice with $30 \mathrm{~cm}$ overlaps. A Russian chamber corer with a diameter of $7.5 \mathrm{~cm}$ was used. All depths refer to the ice (water) surface. Owing to the occurrence of aquatic moss-rich horizons, the cores were easily correlated visually prior to logging and sampling. The total Holocene sediment succession is approximately $4 \mathrm{~m}$ thick. The sediment content of mosses differs significantly and a moss index was therefore applied to describe these changes. The index is based on a visual estimation of the relative moss content in the core and ranges from 0 to 8 . Moss-free sediment is assigned the value 0 , values between 1 and 4 refer to gyttja with moss and values between 5 and 8 refer to increasing degree of moss-gyttja. The majority of the mosses are of the type Drepanocladus exannulatus.

The cores were sampled continuously at $0.5 \mathrm{~cm}$ intervals for geochemical analysis. Samples were freeze-dried and crushed, which means that all weight percentages are dry weight percentages. Magnetic susceptibility $(\chi)$ was measured on all the freeze-dried samples. This was done with a Geofyzica Brno KLY-2 Kappa bridge and the weight of the sediment was determined to allow the calculation of weight-specific SI units $\left(\mu \mathrm{m}^{3} \mathrm{~kg}^{-1}\right)$. The dry weight percentages of sulphur and total carbon content (TC) were measured in a metalyt 905 furnace (standard deviation is \pm 0.2 for sulphur and \pm 0.3 for carbon). There is no $\mathrm{CaCO}_{3}$ in the surrounding basement of the lake and 
therefore TC is taken as being solely organic carbon (TOC). The amount of organic material is estimated by multiplying TOC by 2.5 since organic carbon represents $12 / 30$ of the weight of organic material $\left(\left(\mathrm{CH}_{2} \mathrm{O}\right)_{n}\right)$. The amount of biogenic silica was estimated following the procedure described by Conley and Schelske (2001), which is a modification of the DeMaster methodology (DeMaster, 1979, 1991). In arctic lake sediments biogenic silica is a chemical estimate of diatom and chrysophyte abundance (Conley, 1988). Samples of sediments are weighed and thereafter leached with a mild solution (1\%) of sodium carbonate for a period of 5 hours in a $85^{\circ} \mathrm{C}$ warm bath. Aliquots are withdrawn at 3,4 and 5 hours and analysed for dissolved silica. Biogenic silica is generally dissolved after 2 hours and any further leaching throughout the digestion stems from aluminosilicates. The amount of biogenic silica is estimated from the intercept of the line through the time course aliquots. The accuracy of the method is higher in sediments with high content ( $>10-20 \%$ ) of biogenic silica (Dan Conley, personal communication). In sediments with high biogenic silica concentrations a linear increase in dissolved silica concentration with time is often not found. The analytical error of a sample can be larger than increases in dissolved silica concentration from mineral dissolution (Conley, 1998). In these cases the mean of two extractions of aliquots after 3 hours of dissolution were used instead of the intercept.

The dry weight percentage of clastic material (non-biogenic minerals and rocks) is estimated as 100 minus the sum of dry weight percentage biogenic silica and dry weight percentage organic material. In the following all dry weight percentages are denoted $\%$. The content of water (wet weight percentage) was measured in order to calculate the flux of individual proxies. This was done on 124 samples, and sampling levels were chosen to ensure that the shifting lithology is well-represented. The flux was calculated using the following formula: Flux of proxy $\left(\mathrm{g} \mathrm{cm}^{-2} \mathrm{yr}^{-1}\right)$ :

$$
\begin{aligned}
& \% \text { proxy } / 100 \cdot \text { sedimentation rate }\left(\mathrm{cm} \mathrm{yr}^{-1}\right) \\
& \cdot \text { dry density }\left(\mathrm{g} \mathrm{cm}^{-3}\right)
\end{aligned}
$$

where dry density is calculated as:

$$
\text { wet density }\left(\mathrm{g} \mathrm{cm}^{-3}\right) \cdot(100-\% \text { water })
$$

Wet density is calculated as:

$\left\{\left[\%\right.\right.$ biogenic silica $\cdot$ density biogenic silica $\left.\left(2.1 \mathrm{~g} \mathrm{~cm}^{-3}\right)\right]+$ [\% organic material - density organic material $\left.\left(0.5 \mathrm{~g} \mathrm{~cm}^{-3}\right)\right]$ $+[\%$ (clastic material + sulphur) $\cdot$ density clastic material $\left.\left(2.7 \mathrm{~g} \mathrm{~cm}^{-3}\right)\right]+\left[\%\right.$ water density water $\left.\left.\left(1.0 \mathrm{~g} \mathrm{~cm}^{-3}\right)\right]\right\} / 100$

AMS ${ }^{14} \mathrm{C}$ dating was carried out on 43 samples of mosses, insect remains, terrestrial macrofossils and bulk sediment samples. To check if mosses and bulk samples are as reliable for ${ }^{14} \mathrm{C}$ dating as terrestrial macrofossils, all components were dated on a few levels. In order to standardise ${ }^{14} \mathrm{C}$ dates for fractionation, $\delta^{13} \mathrm{C}$ has been measured in tandem with radiocarbon dating.

\section{Results}

\section{Chronology and sedimentation rate}

Radiocarbon dates were calibrated to calendar years using the terrestrial INTCAL98 dataset from Stuiver et al. (1998) by means of the 1998 version (4.0) of the CALIB program (Stuiver and Reimer, 1993) (Table 1). Calendar age errors are generally small and this permits the construction of a reliable age-depth model (Fig. 2). This was done by applying an eighth-order polynomial function to the calendar ages except for the lower $117.5 \mathrm{~cm}$ and the upper $190.5 \mathrm{~cm}$, which were fitted by a number of linear functions. These were applied with respect to major sediment changes. The missing 470 years in the core top corresponds to at least $15 \mathrm{~cm}$ of loose surface sediments, which could not be retrieved during coring. A sampling interval of $0.5 \mathrm{~cm}$ corresponds to an average resolution of 24 years.

From $11550 \mathrm{cal}$.yr BP until $9300 \mathrm{cal}$.yr BP sedimentation rate is $0.04 \mathrm{~cm} \mathrm{yr}^{-1}$, and decreases to $0.02 \mathrm{~cm} \mathrm{yr}^{-1}$ in the interval $9300 \mathrm{cal}$.yr BP to $6900 \mathrm{cal}$.yr BP. From $6900 \mathrm{cal}$.yr BP sedimentation rate starts increasing slowly and reaches maximum values from 4700 to $4000 \mathrm{cal}^{\mathrm{yr} \mathrm{BP}}\left(0.1 \mathrm{~cm} \mathrm{yr}^{-1}\right)$. From around $3000 \mathrm{cal} . \mathrm{yr} \mathrm{BP}$ to the core top the sedimentation rate is $0.035 \mathrm{~cm} \mathrm{yr}^{-1}$.

\section{Sediments}

Lithology (Fig. 2)

The earliest Holocene sediments in Lake N14 consist primarily of mosses (moss index 6) alternating with clayey and silty algae-rich gyttja layers (Fig. 3A). From 10600 cal.yr BP the sediment is a brown homogeneous algae-rich clay gyttja without mosses (moss index 0). Around $9600 \mathrm{cal}$. yr BP the mosses reappear in a few thin layers with rather sharp boundaries. From 9300 to $4700 \mathrm{cal}$. yr BP the sediments consist of darkbrown algae-rich clay-gyttja with varying content of moss (moss index 1-4). In some levels approximately $1 \mathrm{~cm}$ thin layers of brown-black clayey, very algae-rich moss-gyttja appear (moss index 5). From 4700 until 470 cal. yr BP (top of core) a dark-brown clayey, algae-rich gyttja prevails characterised by somewhat less clay and silt than the underlying sediments. Again the moss content varies between moss indexes 1 and 4. From 4700 until $3900 \mathrm{cal}$. yr BP the moss index changes frequently, followed by an almost constant content of moss (moss index 3) throughout the rest of the Holocene except for two periods of lowered moss content around 24001000 cal. yr BP.

\section{Organic material (Fig. 3A)}

From 11550 to 10200 cal. yr BP organic content is high and fluctuates between $40 \%$ and $80 \%$. Between 10200 and $2600 \mathrm{cal}$. yr BP values gradually increase from $40 \%$ to $60 \%$, but with a tendency of submillennial variability and two marked lows around $9550 \mathrm{cal}$.yr BP and $9400 \mathrm{cal}$. yr BP (Fig. $3 \mathrm{~A})$. From 2600 until $470 \mathrm{cal}$.yr BP values decrease to $30 \%$ with two marked lows around $2400 \mathrm{cal}$.yr BP and $900 \mathrm{cal}$. yr BP. The flux of organic material is overall rather constant $\left(1-2 \mathrm{mg} \mathrm{cm}^{-2} \mathrm{yr}^{-1}\right)$ except for a broad peak centred around $10500 \mathrm{cal} . \mathrm{yrBP}$ and generally high values from 11550 to $9300 \mathrm{cal}$. yr BP (up to $7 \mathrm{mg} \mathrm{cm}^{-2} \mathrm{yr}^{-1}$ ).

\section{$\delta^{13} \mathrm{C}$ values (Fig. 3A, Table 1)}

$\delta^{13} \mathrm{C}$ values in organic material increase from $-23 \%$ to $-17 \%$ between 11550 and $11100 \mathrm{cal}$. yr BP and decrease to $-20 \%$ around $10700 \mathrm{cal} . y \mathrm{BP}$. From $10600 \mathrm{cal}$.yr BP values are relatively high $(-17 \%)$, but decrease to $-25 \%$ from $10000 \mathrm{cal} . y r$ BP until ca. $7300 \mathrm{cal}$.yr BP. From 7300 to 1000 cal. yr BP values are again relatively high $(-18 \%)$ but with fluctuations of $1-3 \%$. 


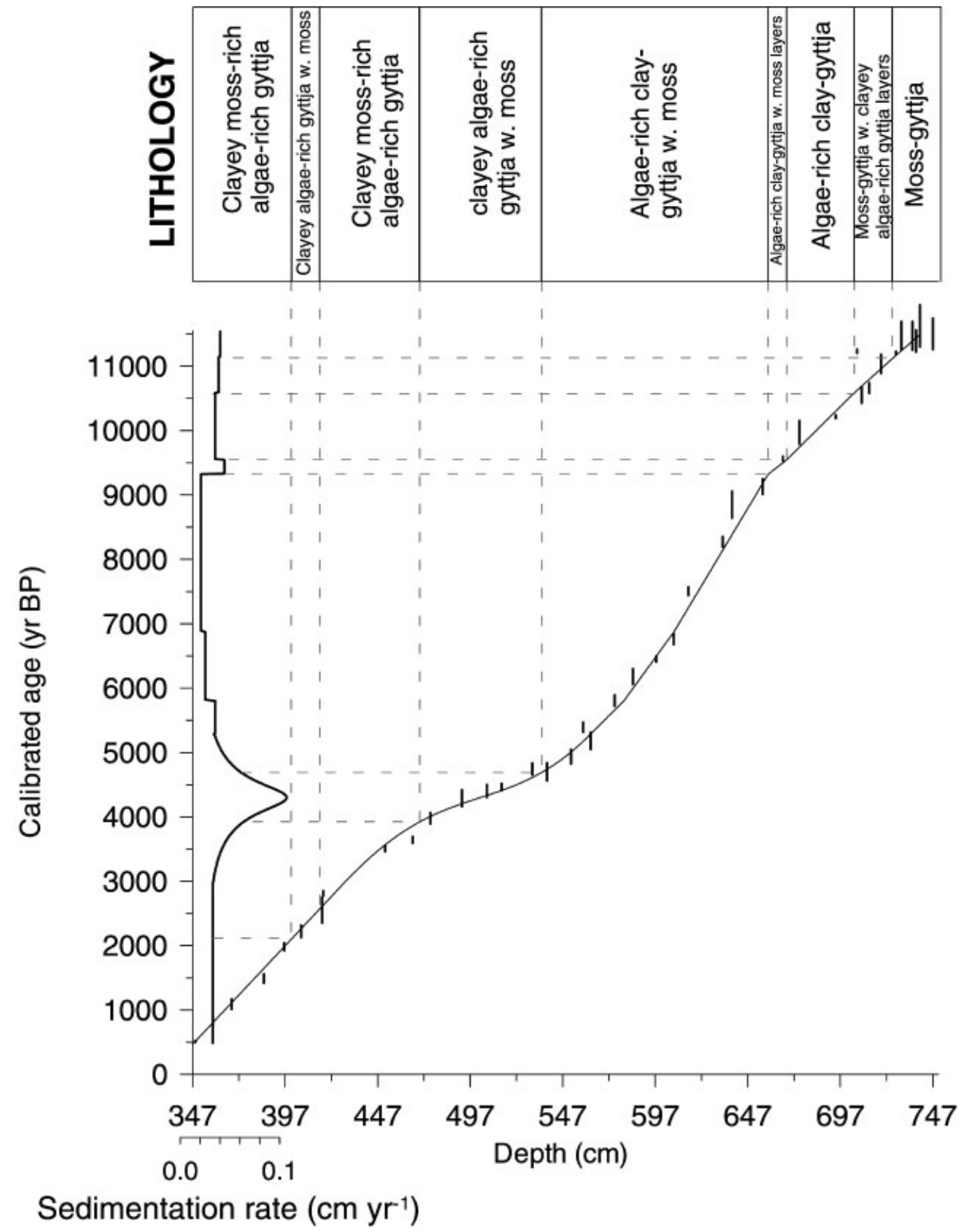

Figure 2 Calibrated ages are shown as a function of depth and with the interpreted age model. Sedimentation rate $\left(\mathrm{cm}^{-1} \mathrm{r}^{-1}\right)$ and major lithological boundaries are also indicated

Biogenic silica (Fig. 3B)

From 11550 until 10700 cal. yr BP \% biogenic silica is low (3$5 \%$ ). At 10700 a rapid increase to values around $20 \%$ is observed and this is followed by another sharp increase at $9500 \mathrm{cal}$.yr BP to values around $25 \%$. Around $8000 \mathrm{cal}$.yr BP values increase to nearly $30 \%$ and remain high and rather stable until $4000 \mathrm{cal}$. yr BP. Then values start decreasing slowly until $470 \mathrm{cal} . y \mathrm{BP}$ except for three minor peaks centred around 2400 cal. yr BP, 900 cal. yr BP and 600 cal. yr BP. Flux of biogenic silica is extremely low at $11550 \mathrm{cal}$. yr BP but increases rapidly at 10700 cal. yr BP to $1.5 \mathrm{mg} \mathrm{cm}^{-2} \mathrm{yr}^{-1}$. This value is maintained for the rest of the Holocene except for a broad peak $4700-4000 \mathrm{cal} . \mathrm{yr} \mathrm{BP}\left(4 \mathrm{mg} \mathrm{cm}^{-2} \mathrm{yr}^{-1}\right)$ and two minor peaks at 2400 cal. yr BP and 900 cal. yr BP $\left(2 \mathrm{mg} \mathrm{cm}^{-2} \mathrm{yr}^{-1}\right)$.
Clastic material (Fig. 3C)

From 11550 to $9300 \mathrm{cal}$.yr BP amount of clastic material is very variable with a marked low (1-2\%) at $10600 \mathrm{cal}$.yr BP and two marked peaks $(60 \%)$ at $9550 \mathrm{cal} . \mathrm{yrBP}$ and 9400 cal. yr BP. From 9300 cal. yr BP values gradually decrease from $40 \%$ to $15 \%$ until 2600 cal.yr BP. From 2600 until $470 \mathrm{cal}$.yr BP values increase gradually to $30 \%$ with two minor peaks (nearly $40 \%$ ) centred at $2400 \mathrm{cal}$.yr BP and 900 cal. yr BP. The flux of clastic material is high and variable from $11550 \mathrm{cal}$.yr BP until $9300 \mathrm{cal}$.yr BP. Major peaks are observed at $9550 \mathrm{cal}$.yr BP and $9400 \mathrm{cal}$.yr BP $\left(6 \mathrm{mg} \mathrm{cm}^{-2} \mathrm{yr}^{-1}\right)$ whereas a low $\left(1 \mathrm{mg} \mathrm{cm}^{-2} \mathrm{yr}^{-1}\right)$ is centred around $10600 \mathrm{cal} . y r$ BP. From 9300 to $1500 \mathrm{cal} . y r$ BP values are low and decrease slightly from 2 to $1 \mathrm{~g} \mathrm{~cm}^{-2} \mathrm{yr}^{-1}$ 
Table 1 Radiocarbon dates from Lake N14

\begin{tabular}{|c|c|c|c|c|c|}
\hline Depth $(\mathrm{cm})$ & Dated material & $\delta^{13} \mathrm{C}(\%$ PDB $)$ & ${ }^{14} \mathrm{C}$ age $\left({ }^{14} \mathrm{C}\right.$ yr BP $)$ & Calibrated age (cal. yr BP) & Laboratory number \\
\hline $349.5-348.5$ & Bulk & -22.3 & $445 \pm 35$ & $525-505$ & AAR-6438 \\
\hline $359-358$ & Bulk & -22.9 & $910 \pm 35$ & 905-759 & AAR-6439 \\
\hline $368-367$ & Moss & -17.7 & $1190 \pm 50$ & $1170-1010$ & AAR-5800 \\
\hline $385.5-384.5$ & Moss & -16.9 & $1625 \pm 50$ & $1560-1420$ & AAR-5830 \\
\hline $396.5-395.5$ & Moss & -18.7 & $1950 \pm 45$ & 2041-1925 & AAR-5829 \\
\hline $405.5-404.5$ & Moss, Chitinous matter & -18.7 & $2205 \pm 45$ & $2315-2129$ & AAR-5828 \\
\hline $417.5-417$ & Bulk & -21.9 & $2710 \pm 35$ & $2851-2775$ & AAR-5835 \\
\hline $417-416.5$ & Moss, Chitinous matter & -19.2 & $2575 \pm 50$ & $2750-2620$ & AAR-5826 \\
\hline $417-416.5$ & Piece of twig & -22.6 & $2440 \pm 40$ & $2711-2355$ & AAR-5827 \\
\hline $451-449.5$ & Moss, Chitinous matter & -18.6 & $3275 \pm 40$ & $3555-3465$ & AAR-5825 \\
\hline $466-465.5$ & Moss & -19.9 & $3400 \pm 40$ & $3690-3590$ & AAR-5824 \\
\hline $475.5-475$ & Moss & -19.4 & $3645 \pm 40$ & $4065-3895$ & AAR-5823 \\
\hline $492.5-492$ & Moss, Chitinous matter & -18.6 & $3880 \pm 65$ & $4415-4159$ & AAR-5822 \\
\hline $506-505.5$ & Moss, Chitinous matter & -18.9 & $3950 \pm 35$ & $4500-4304$ & AAR-5821 \\
\hline $530.5-530$ & Moss, Chitinous matter & -18.4 & $4210 \pm 40$ & $4835-4655$ & AAR-5819 \\
\hline $538.5-537.5$ & Moss, Chitinous matter & -19.0 & $4160 \pm 50$ & $4840-4560$ & AAR-5818 \\
\hline $551.5-551$ & Moss, Chitinous matter & -19.3 & $4410 \pm 45$ & $5047-4871$ & AAR-5816 \\
\hline $551.5-551$ & Piece of twig & -24.6 & $4245 \pm 35$ & $4845-4825$ & AAR-5817 \\
\hline $558-557.5$ & Moss, Chitinous matter & -19.5 & $4680 \pm 40$ & $5470-5320$ & AAR-5815 \\
\hline $562-651.5$ & Moss, Chitinous matter & -19.0 & $4530 \pm 60$ & $5310-5050$ & AAR-5814 \\
\hline $575-574.5$ & Moss, Chitinous matter & -18.2 & $5040 \pm 50$ & $5890-5720$ & AAR-5813 \\
\hline $585-584.5$ & Moss, Chitinous matter & -19.0 & $5430 \pm 90$ & $6300-6060$ & AAR-5812 \\
\hline $597.5-597$ & Bulk & -21.0 & $5680 \pm 40$ & 6496-6410 & AAR-5834 \\
\hline $607-606.5$ & Moss & -20.5 & $5930 \pm 45$ & $6845-6675$ & AAR-5811 \\
\hline 615-614 & Moss & -19.1 & $6635 \pm 50$ & $7570-7440$ & AAR-5810 \\
\hline $633.5-633$ & Moss & -24.3 & $7410 \pm 65$ & 8350-8190 & AAR-5809 \\
\hline $638.5-638$ & Moss & -25.7 & $8085 \pm 60$ & 9060-9000 & AAR-5808 \\
\hline $638.5-638$ & Bulk & -20.9 & $7945 \pm 50$ & 8990-8640 & AAR-5833 \\
\hline $655-654.5$ & Moss & -24.6 & $8130 \pm 75$ & 9250-9010 & AAR-5807 \\
\hline $666-665$ & Moss & -23.4 & $8615 \pm 55$ & 9600-9530 & AAR-5806 \\
\hline $706-705.5$ & Moss & -17.5 & $9855 \pm 50$ & $11260-11200$ & AAR-5802 \\
\hline $708.5-780$ & Moss & -20.4 & $9335 \pm 60$ & $10670-10430$ & AAR-5805 \\
\hline $712.5-712$ & Moss & -19.6 & $9445 \pm 55$ & $10740-10580$ & AAR-5804 \\
\hline $719-718.5$ & Moss & -18.9 & $9690 \pm 70$ & 11 180-10890 & AAR-5803 \\
\hline $727-726.5$ & Moss & -17.5 & $9810 \pm 60$ & $11230-11180$ & AAR-5801 \\
\hline $730.2-729.8$ & Moss & -20.2 & $10025 \pm 90$ & $11690-11260$ & Ua-15 411 \\
\hline $736.2-735.8$ & Moss & -21.1 & $10005 \pm 95$ & $11690-11250$ & Ua-15 410 \\
\hline 738.1-737.9 & Moss & -22.3 & $9955 \pm 85$ & $11560-11220$ & Ua-15 409 \\
\hline $740.1-739.9$ & Moss & -22.7 & $10100 \pm 100$ & $11950-11300$ & Ua-14925 \\
\hline $747.1-746.9$ & Moss & -22.0 & $10040 \pm 95$ & $11740-11260$ & Ua-15 407 \\
\hline
\end{tabular}

followed by a small increase. A major broad peak $\left(4 \mathrm{mg} \mathrm{cm}^{-2} \mathrm{yr}^{-1}\right)$ is observed from 4700 to $4000 \mathrm{cal} . \mathrm{yr} \mathrm{BP}$ and two minor peaks $\left(2 \mathrm{mg} \mathrm{cm}^{-2} \mathrm{yr}^{-1}\right)$ are observed at $2400 \mathrm{cal}$. yr BP and $900 \mathrm{cal}$. yr BP.

\section{Magnetic susceptibility (Fig. 3D)}

Between 11550 and 10700 cal. yr BP values are relatively high but decrease from 10 to $5 \mu^{3} \mathrm{~kg}^{-1}$. From 10700 cal.yr BP values remain constantly low, but start increasing around 1500 cal. yr BP to $8-10 \mu \mathrm{m}^{3} \mathrm{~kg}^{-1}$.

\section{Sulphur (Fig. 3E)}

From 11550 to $10600 \mathrm{cal}$.yr BP values are high but show a general decrease from $5 \%$ to $1 \%$. Around $9500 \mathrm{cal} . \mathrm{yrBP}$ values increase to $1.5 \%$ but decrease to around $1 \%$ at 8000 cal. yr BP. The interval $11550-8000 \mathrm{cal}$. yr BP is characterised by higher-frequency variability than the interval
$8000-470$ cal. yr BP. From 8000 to 3000 cal. yr BP values are low $(0.5-1 \%)$, but with minor peaks around $7000 \mathrm{cal}$. yr BP and $5500 \mathrm{cal}$. yr BP. From 3000 until $470 \mathrm{cal}$. yr BP values gradually increase to $1.5 \%$ with a major short-lived peak of $>2 \%$ at 2000 cal.yr BP. From 11550 to 8000 cal.yr BP flux of sulphur is high but generally decreases from 0.15 to $0.03 \mathrm{mg} \mathrm{cm}^{-2} \mathrm{yr}^{-1}$, with three peaks centred at 10500 $11500 \mathrm{cal} . \mathrm{yr} \mathrm{BP}, 9500 \mathrm{cal}$.yr BP and $8500 \mathrm{cal}$.yr BP. From 6000 to 3500 cal.yr BP a flux peak $\left(1 \mathrm{mg} \mathrm{cm}^{-2} \mathrm{yr}^{-1}\right)$ is observed and two additional peaks $\left(1.5 \mathrm{mg} \mathrm{cm}^{-2} \mathrm{yr}^{-1}\right)$ are centred at $2000 \mathrm{cal}$.yr BP and $1000 \mathrm{cal}$.yr BP. In spite of low percentage values of sulphur the variability exceeds the standard deviation of $\pm 0.2 \%$.

\section{Discussion}

\section{Environmental interpretation}

The interrelationship between the investigated proxies is illustrated by a plot of the first and second axis score of variables, 


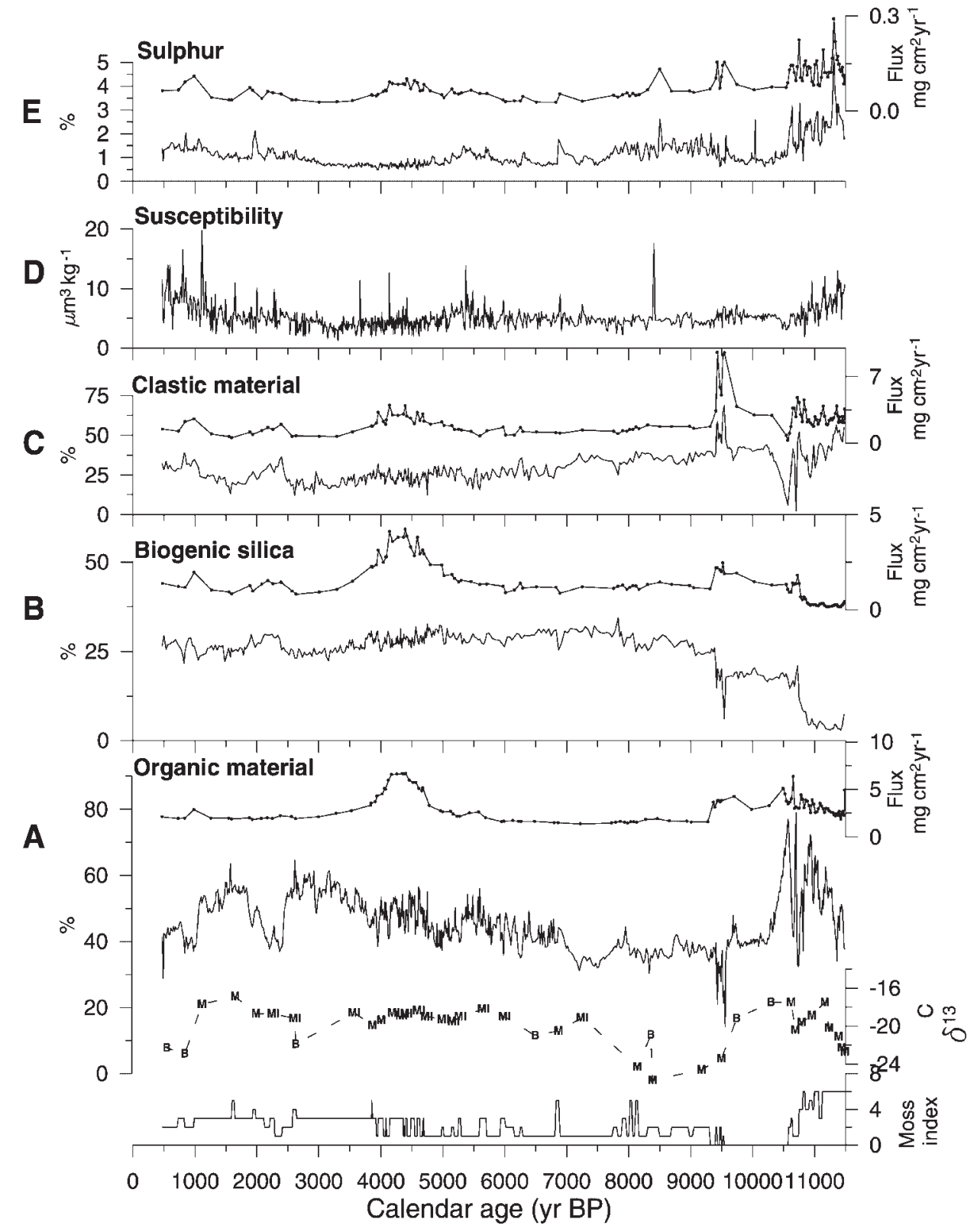

Figure 3 Weight percentage $(\%)$ and flux $\left(\mathrm{mg} \mathrm{cm}^{-2} \mathrm{yr}^{-1}\right)$ data. $\mathrm{A}$, organic material. Also shown is visual moss index and $\delta^{13} \mathrm{C}$ in radiocarbon dated material $(M=$ moss, $M I=$ moss with very low amounts of chitinous remains, $B=$ bulk). B, biogenic silica. C, clastic material. $D$, susceptibility (susceptibility/g). E, Sulphur

obtained from a principal component analysis (PCA) using Canoco 4.0 (ter Braak and Smilauer, 1998) (Fig. 4). The matrix was based on percentage data, moss index, magnetic susceptibility and sedimentation rate versus age. The eigenvalue of the first axis is 0.82 , which means that most of the variance in the dataset is explained by this axis. Organic material is positively correlated to moss content and these two parameters have a positive influence on sedimentation rate. Sulphur and susceptibility are more related to clastic material and the latter is negatively correlated to organic material. Biogenic silica is surprisingly more correlated to clastic material than to organic material. These interrelationships are particularly strong during the last 9300 years, so the biplot is shown for this period (Fig. 4).

We propose a scenario in Lake N14 with sediment changes being mainly related to precipitation changes. Arctic diatom abundance is dependent on lake-water nutrient levels (Bennion et al., 1996; Ryves et al., 2002) and this may explain why biogenic silica co-varies with input of clay and silt, which is mainly transported by surface runoff. During years of heavier winter snowfall, spring melt enhances surface runoff and thereby transports more clastic material and silica into the lake for diatoms to build frustules from. In contrast, dry periods are characterised by less surface runoff and the decreased diatom production creates clear lake water and good light conditions on the lake bottom. The aquatic mosses Sphagnum subsecundum and Drepanocladus exannulatus are more dependent on light conditions than on temperature (Riis and Sand-Jensen, 1997), and this could explain the increased moss abundance (mainly Drepanocladus exannulatus) with decreasing biogenic silica and clastic material content. It should be noted that some of the biogenic silica variability may also be related to temperature changes, but it is not possible to differentiate between the influence of temperature and precipitation on the lake sediment composition. It is likely that warmer temperatures were associated with enhanced precipitation and surface runoff during the Holocene and this would imply that increased biogenic silica and clastic material imply warm periods whereas moss implies colder periods. This theory is supported by the tendency for enriched values of $\delta^{13} \mathrm{C}$ in radiocarbon dated mosses 


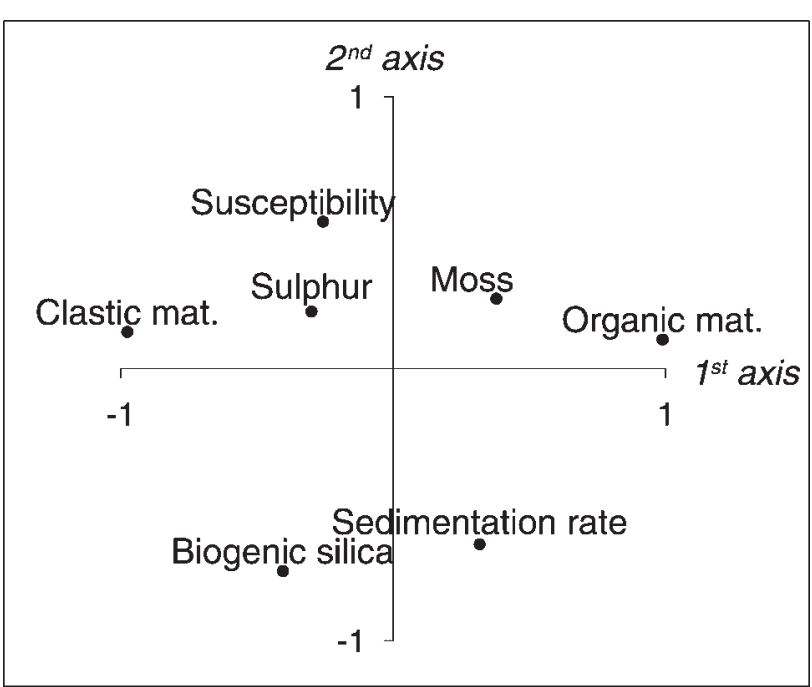

Figure 4 PCA ordination plot of values of biogenic silica (\%), sulphur $(\%)$, organic material $(\%)$, clastic material (\%), moss index, sedimentation rate $\left(\mathrm{mm} \mathrm{yr}^{-1}\right)$ and susceptibility $\left(\mu \mathrm{m}^{3} \mathrm{~kg}^{-1}\right)$ during the youngest 9300 years of the dataset. Eigenvalues of first and second axes are 0.82 and 0.08 , respectively

with increasing moss content (Fig. 3A). There are two processes which may be able to explain variability in the ${ }^{13} \mathrm{C}$ content of the mosses. First, during aquatic photosynthesis dissolved inorganic carbon in the boundary layer surrounding the plant is enriched in ${ }^{13} \mathrm{C}$, due to the preferential use of ${ }^{12} \mathrm{C}$ in plant photosynthesis. The more stagnant the boundary layer is, the more ${ }^{13} \mathrm{C}$-enriched the dissolved inorganic material and thereby the moss will be (Osmond et al., 1981; Keeley and Sandquist, 1992; Hecky and Hesslein, 1995). Stagnant boundary layers are likely to occur during periods with lake ice-and therefore the enrichment in $\delta^{13} \mathrm{C}$ observed during dry, mossrich periods may also reflect relatively low temperatures. Second, decomposition of organic material influences the $\delta^{13} \mathrm{C}$ content in mosses. Degradation and oxidation of organic plant material releases $\mathrm{CO}_{2}$ with a high ${ }^{12} \mathrm{C}$ content (Deines, 1980). This may lead to a depletion of ${ }^{13} \mathrm{C}$ in the dissolved inorganic carbon and subsequently in new mosses (Rau, 1978). Therefore it could be expected that with increasing water temperatures the decomposition of organic material increased due to higher amounts of bacteria. The result would then be lower $\delta^{13} \mathrm{C}$ values during warmer intervals. In summary, prolonged lake ice-cover/colder conditions will result in enriched values of $\delta^{13} \mathrm{C}$ of moss. As moss content increases with increasing values of $\delta^{13} \mathrm{C}$ this indicates that increased moss content is associated not only with drier but also with colder climatic conditions.

A noticeable feature is that the content of sulphur is much higher $(0.5-5 \%)$ than usually observed in lake sediments (0.5-1\%) (Berner and Raiswell, 1984). Given the proximity to the sea and the fact that the bedrock does not contain sources of sulphur (e.g. there are no veins or evaporites) the most likely source of sulphur to the sediments is sea salt spray. $\mathrm{NaSO}_{4}$ is highly mobile in sediment, but the high-frequency variability in sulphur values suggests that $\mathrm{NaSO}_{4}$ must have been fixed into the sediment shortly after deposition. Fixation occurs via bacterial reduction of $\mathrm{NaSO}_{4}$ to pyrite (Berner and Raiswell, 1984), which is re-oxidised to $\mathrm{NaSO}_{4}$ after coring and freezedrying. Organic content is relatively high and is therefore not believed to be a limiting factor for pyrite production. It is therefore assumed that changes in sulphur reflect changes in the actual input of $\mathrm{NaSO}_{4}$ to the lake. The most important parameters considered when explaining variations in sea salt spray would in this case be magnitude and frequency of wind and storms, stirring up droplets of seawater into the air, as well as the magnitude of protecting sea ice cover. This makes sulphur a difficult climate proxy, as cold climate with increased sea iceladen polar waters usually is also associated with enhanced storm frequency. Thus, the same climatic conditions cause both enhanced and diminished sea salt spray to the lake.

As the earliest Holocene data exhibit higher amplitude and variability than the younger Holocene, the Holocene climatic history is divided into two intervals: $11550-9300$ cal. yr BP and 9300-470 cal.yr BP (top of core). To investigate the earliest Holocene interval fluxes are used (Fig. 5) whereas the 9300$470 \mathrm{cal}$. yr BP period is investigated in terms of \% data as the sampling density of flux data in this interval is low.

\section{Holocene climate variability}

\section{500-9300 cal. yr BP}

The onset of the Holocene in Lake N14 is described in detail by Björck et al. (2002). They concluded that the Younger Dryas Stadial (12 800-11 550 cal. yr BP) was characterised by an arid climate with cold winters and anomalously mild summers. The interpretation of warm summers is based on high lake productivity and increased $\mathrm{pH}$ of lake water due to increased nutrient load during the growing season. It was suggested that high insolation and local climatic föhn winds could explain the anomalously warm summers. The transition to the Holocene is characterised by a sudden dominance of aquatic mosses. Björck et al. (2002) interpreted this as a change towards a more humid climate resulting in increased surface runoff along with cooler summers causing decreased lake productivity and thereby better light conditions at the bottom favouring moss growth.

From around $11125 \mathrm{cal}$.yr BP (Fig. 5) intermittent layers of algae-rich gyttja become increasingly common and this is interpreted as being due to periods of increased surface runoff. These periods of increased precipitation are associated with increased sea salt spray. The reason for this could be that the northward displacement of the low pressure tracks causing increased precipitation also produces ice-free conditions in the surrounding ocean. With less protective ice pack, wind can transport more sea salt to the lake. Björck et al. (2002) found that the diatom flora at the level corresponding to 11 100-10 800 cal. yr BP suggested a cooling which could correspond to the Preboreal Oscillation (PBO). This is supported by the notion of a concurrent minor peak in moss abundance indicating arid and cold conditions. The younger age of the PBO (dated to 11200 cal. yr BP in Björck et al. (1997, 2002)) in the Holocene age model of Lake N14 could be explained by a less reliable age model in this early Holocene interval due to changing lithologies.

The rapidly increasing diatom and organic material production, along with decreased clastic material input between 10750 and $10600 \mathrm{cal}$.yr BP, marks a transition into warmer conditions along with decreased surface runoff. The latter could be due to an early stabilisation of the surrounding catchment. Moss decreases while organic material increases-this implies that the aquatic productivity is highly influenced by algae. A short-lived event of decreased input of biogenic silica, organic material and clastic material to the lake and high $\delta^{13} \mathrm{C}$ values (Fig. 3A) and moss content is observed around $10625 \mathrm{cal}$.yr BP and could be related to increased lake-ice cover. The cold climate is accompanied by increased sea salt spray — perhaps storm related — as indicated by increased sulphur flux. 


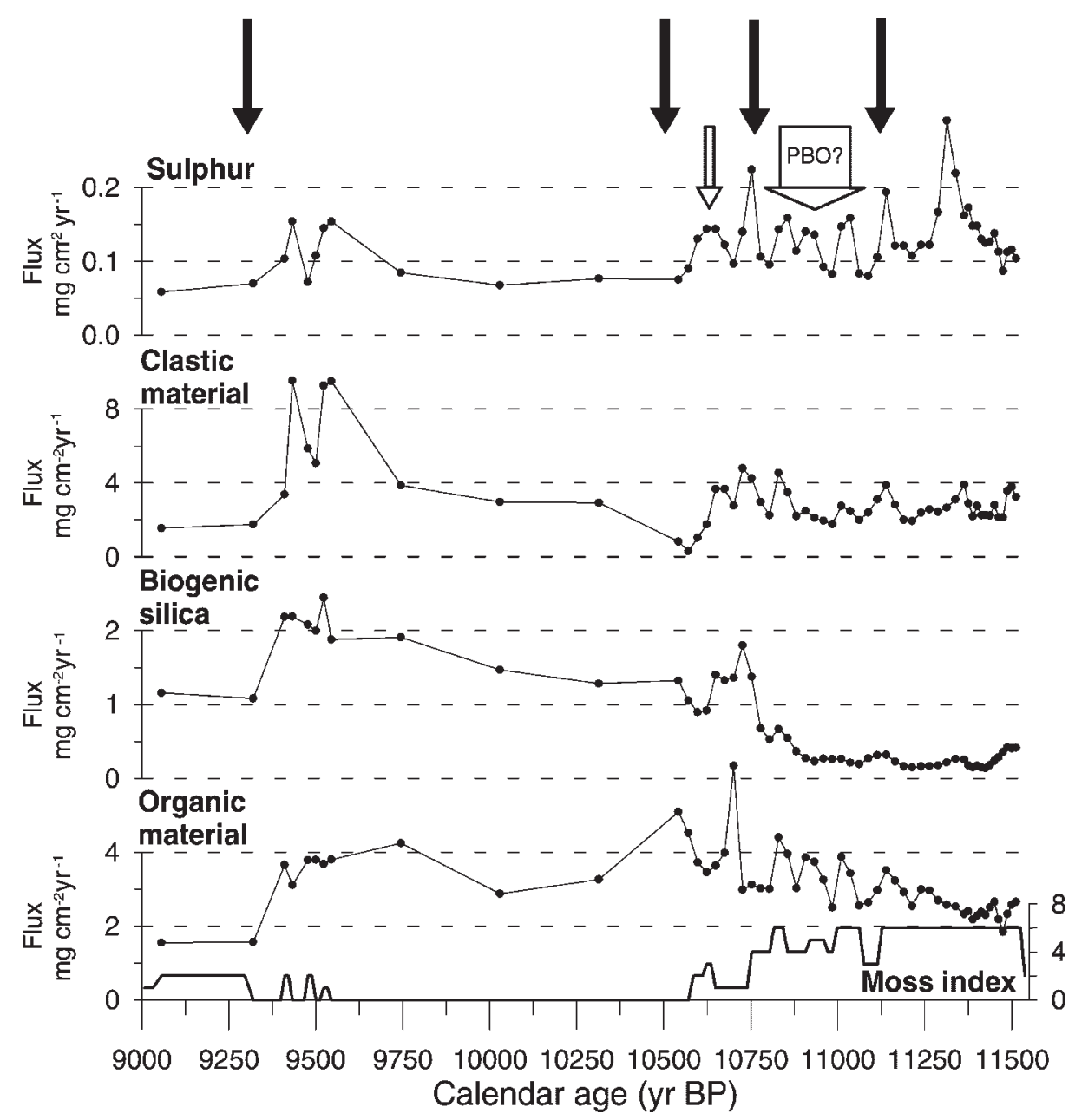

Figure 5 A close-up of flux data $\left(\mathrm{mg} \mathrm{cm}^{-2} \mathrm{yr}^{-1}\right)$ from the period 11 500-9000 cal. yr BP. Also shown is visual moss index. Dark arrows mark transitions to warmer and more humid conditions. Light arrow marks cold and arid event

The period $10600-9550$ cal. yr BP is characterised by a complete lack of mosses along with a rather high flux of organic material and biogenic silica. This marks the onset of increased warming and probably also humid conditions. This could be related to a general northward shift of the Icelandic low to its present position. The interpretation of the early Holocene development in the lake, as being a response to increased warming and/or humid conditions, concurs with Greenland ice cores documenting rapid warming and more humid conditions during the earliest two to three millennia of the Holocene (Dansgaard et al., 1993; Alley et al., 1997; Johnsen et al., 2001). Episodes of strongly increased clastic input are observed around 9550 and $9400 \mathrm{cal}$. yr BP and these are accompanied by peaks in sulphur. Each event is followed by a thin moss layer. These events are interpreted as extreme precipitation events with intermittent cold periods (moss layers). The increased sea salt spray could in this case again be related to increased storm activity.

From $9300 \mathrm{cal}$.yr BP fluxes of all parameters decrease, although moss reappears as an important component of the sediments and remains so throughout the rest of the Holocene. Decreased fluxes probably mark the onset of a more stable climatic regime which stabilised the surrounding catchment and decreased the surface runoff. A more dense vegetation cover could also have contributed to this stabilisation.

In summary, the earliest Holocene data marks a general transition from a late-glacial dry and cold climate to a more humid and mild climate. This interpretation concurs with Greenland ice cores documenting rapidly increasing warming and precipitation during the earliest two to three millennia of the Holocene (Dansgaard et al., 1993; Alley et al., 1997; Johnsen et al., 2001). This is also recognised by Koc et al. (1993) who, on the basis of SST reconstructions from diatom data, found that the onset of the Holocene was characterised by a northwesterly retreat of the sea-ice margin and the Polar Front from the eastern part of the Nordic Sea to a position off Greenland and an associated rapid temperature increase of almost $10^{\circ} \mathrm{C}$. The highly variable alternations between dry (indicating moss) and wet (indicating clastic material and diatoms) illustrate the unstable and fluctuating nature of the displacement of this frontal system (Taylor et al., 1993).

\section{0-470 cal. yr BP}

The content of biogenic silica is used as the main proxy for precipitation changes during the period 9300-470 cal.yr BP (Fig. 4), but it is possible that increased biogenic silica also implies increased temperature, as indicated by the carbon isotope data. It is assumed that the increased precipitation increased surface runoff and the associated increased nutrient level in the lake water increased diatom and chrysophyte production. The increased production could result in diminished light conditions on the lake bottom, which would explain the associated decrease in moss abundance. Furthermore, the $\delta^{13} \mathrm{C}$ content in moss decreases with decreasing moss content, which was interpreted as the result of warm climatic conditions. 
However, there is no correlation on a centennial time scale between the biogenic silica and inferred precipitation data from the GISP2 accumulation record (Fig. 6E) and inferred temperature data from the DYE-3 ice core (Fig. 6F). In contrast, the longterm increase in biogenic silica 9000-7500 cal. yr BP, followed by an overall decrease for the rest of the Holocene, is similar to the long-term trend in the inferred temperature record from the DYE3 ice core.

A study of Holocene lake sediments from western Greenland showed a close correlation on a centennial time scale with the GRIP $\delta^{18} \mathrm{O}$ record but less correlation with the GISP2 record (Willemse and Törnqvist, 1999). Thus, in western Greenland there are indications of high-altitude Holocene climate variability being linked to lower altitudes. The lack of a close correlation between centennial climate variability as inferred from Lake N14 and the top of the ice sheet may perhaps be related to the extreme maritime conditions in southernmost Greenland.

The 8200 cal. yr BP event (Dansgaard et al., 1993; Barber et al., 1999) may perhaps be evident in the N14 record as a dry and cold period $8400-8000$ cal.yr BP; however, if this cooling is related to the $8200 \mathrm{cal}$. yr BP event, it is far from as distinct as inferred from the Greenland ice core records (Fig. 6E,F) (Johnsen et al., 2001; Alley et al., 1997).

From 9300 cal. yr BP the climate in south Greenland is more stable, although still variable, than during the earliest Holocene (Fig. 6C). Relatively high content of biogenic silica around $8000-5000$ cal. yr BP, with maximum relative content 80006500 cal. yr BP, probably corresponds to Holocene climatic optimum conditions, with the overall atmospheric circulatory pattern causing a warmer and more humid climate in southern Greenland. This is also supported by relatively markedly decreased values of $\delta^{13} \mathrm{C}$ during much of the period (Fig. 3A), explained by a combination of decreased annual lake-ice cover and increased decomposition and recycling of carbon due to increased lake-water temperatures. Additional studies on a number of lakes in southern Greenland have also shown Holocene optimum climatic conditions around 8000$5000 \mathrm{cal} . y r$ BP (Funder and Fredskild, 1989). The peak in Holocene climatic optimum conditions around 80006500 cal. yr BP as inferred from Lake N14 is in accordance with the ice-core data from DYE-3 documenting peak Holocene warming around 8000-7000 cal.yr BP (Johnsen et al., 2001). Holocene climatic optimum conditions occurred around 6000-3000 yr BP on the southwest Greenland coast according to biogenic silica variations from Qipisarqo Lake (Kaplan et al., 2002), and the local delay of warming was ascribed to the cooling influence of the proximal Greenland Ice Sheet.

The high peak in sedimentation rate of both organic and clastic material, biogenic silica and sulphur 4700-4000 cal. yr BP is concordant with a highly fluctuating moss index and is most likely related to the first sign of a mid-Holocene climate deterioration, which is frequently termed 'Neoglaciation'. The low pressure system could have been situated in a sensitive position in relation to south Greenland, thereby creating high-frequency climatic changes. This would mark the first signs of a reorganisation of the atmospheric circulatory pattern at the transition from Holocene optimum conditions to the early onset of Neoglaciation in the North Atlantic region.

The earliest Holocene development into more humid conditions prevail until ca. $3700 \mathrm{cal}$. yr BP and is followed by a generally drier climate. On the broad trend (Fig. 6C) are superimposed centennial and millennial climatic changes, which increase in amplitude between 3700 and 470 cal. yr BP. In particular the periods $3700-2400 \mathrm{cal} . \mathrm{yr} B \mathrm{~B}$ and 1800 600 cal. yr BP are characterised by dry conditions. From around $3700 \mathrm{cal} . y r \mathrm{BP}$ colder and more arid conditions had thus commenced in southern Greenland as indicated by the decreased biogenic silica content. The transport of sea-ice and icebergs to south Greenland probably increased-especially during dry and cold periods. This agrees fairly well with Koc et al. (1993) who date the onset of southward movement of the Polar Front to $3300 \mathrm{cal}$.yr BP and Funder and Fredskild (1989) who date the onset of the Neoglaciation in south Greenland to $3200 \mathrm{cal}$. yr BP.

It is noted that sea salt spray was generally higher during the intervals $9300-8000 \mathrm{cal} . y r$ BP, $5700-4000 \mathrm{cal}$. yr BP and 1200-600 cal.yrBP (Fig. 6A,B). It seems likely that the increased sea salt spray is mainly related to increased annual storminess. The overall increase in sea salt spray in the Early and Late Holocene would then be related to an overall harsher climate whereas the increased sea salt spray in the Middle Holocene may be related to the initial major reorganisation of the atmospheric circulatory pattern starting around $4700 \mathrm{cal}$. yr BP. An important exception from this tendency is seen during the dry and cold periods 3700-2400 cal.yr BP and 1800-1200 cal. yr BP where sea salt spray is at a minimum. An explanation for this could be that the Late Holocene cold periods are accompanied by an increased EGC. The associated increase of sea-ice would then have protected the ocean from wind stirring up sea salt. An additional reason for the higher Late Holocene values may be a rising sea level in the later part of the Holocene (Bennike and Björck, 2000; Bennike et al., 2002). Falling sea-level due to isostatic rebound may also partly explain the decreasing sulphur trend in the first half of the Holocene. The sea salt record (SSNa) from the GISP2 ice core (O'Brien et al., 1995) is in accordance with the lake N14 record of sea salt spray (on basis of percentage sulphur) between 9300 and 8000 cal.yr BP, 6200 and 5000 cal.yr BP and around $1000 \mathrm{cal} . \mathrm{yr} \mathrm{BP}$. The restricted correspondence between additional sea salt spray events in the GISP2 and Lake $\mathrm{N} 14$ records may be related to local conditions in the Lake N14 area influencing sea salt spray (sea-ice and storm activity).

It has been suggested that the period from around 1100 cal. yr BP until 700-600 cal. yr BP was characterised by high wind activity along a track from East Canada (Kasper and Allard, 2001), southern Greenland (Lassen et al., 2004; Roncaglia and Kuijpers, 2004) to northwestern Iceland (Andresen et al., submitted). This is supported in our data by a series of peaks in sea salt spray between 1200 and 600 cal. yr BP along with peaks in aridity. In contrast, it is noted that the opposite trend occurs around 1000-900 cal.yr BP; a short-lived event of decreased sea salt spray occurs along with humid conditions. This short-lived event may be part of the socalled 'Medieval Warm Period'. However, the Qipisarqo lake record (Kaplan et al., 2002) in southwestern Greenland indicates a more prolonged interval of ameliorated climatic conditions between 1300 and 900 cal.yr BP. The 'Medieval Warm Period' was probably not a synchronous circum-North Atlantic event, but rather an interval of regional asynchronous periodic warmings interrupted by relatively colder intervals (Hughes and Diaz, 1994). It could be hypothesized that the colder conditions during the Middle Ages in southernmost Greenland (Lake N14) in comparison with southwestern Greenland (Qipisarqo Lake) could be explained by a larger influence from the EGC.

The biogenic silica data have been compared to a marine record of haematite stained grains from the northeastern Atlantic (VM29-191), which have been interpreted to reflect windinduced inflow of drift ice from the EGC (Bond et al., 2001). From around $7000 \mathrm{cal}$.yr BP centennial periods of increased drift ice to more southerly areas of the North Atlantic Ocean tend to concur with cold and arid periods in southern Greenland. If indeed this suggests a land-ocean link in climate 


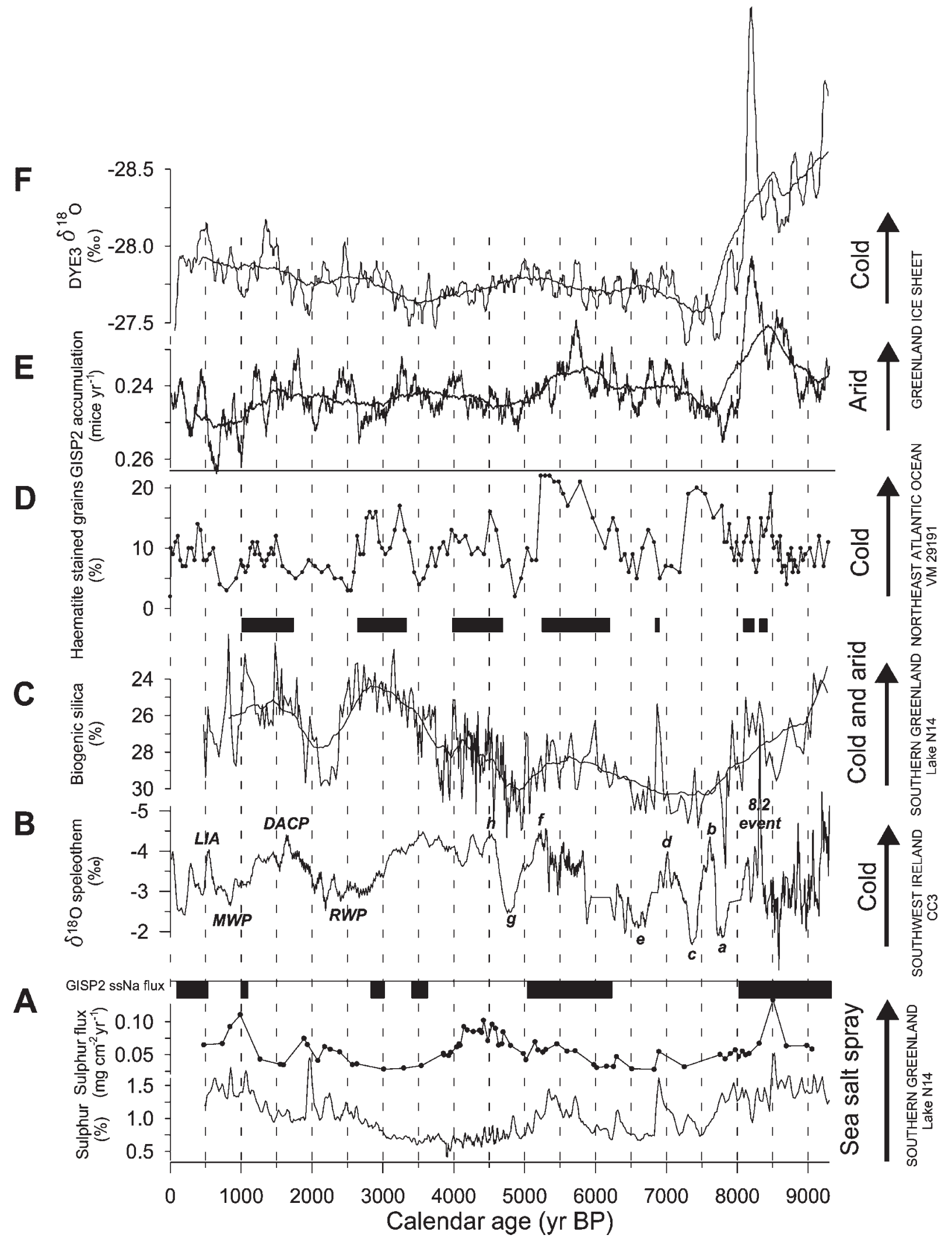

Figure 6 Comparison of precipitation and sea salt spray data from lake N14 with other proxy studies. A, sulphur (\%) (three-point running mean) and sulphur flux $\left(\mathrm{mg} \mathrm{cm}^{-2} \mathrm{yr}^{-1}\right)$ from Lake N14. As flux data are relatively sparse the percentage data is used in addition to indicate high-frequency variability in sea salt spray. Black boxes denote periods with increased flux of sea salt to the Greenland ice sheet (O'Brien et al., 1995). B, CC3 $\delta^{18} \mathrm{O}$ (VPDB) record from Irish stalagmite. Letters refer to marked cold and warm events correlated to the GISP2 $\delta^{18}$ O record by McDermott et al. (2001). C, biogenic silica (\%) from Lake N14. The data is applied with a 25-point running mean (corresponding approximately to an 800-year running mean). D, haematite stained grains (\%) used as a proxy for drift ice. From VM29-191 cored east of Ireland in the North Atlantic Ocean (Bond et al., 2001). Boxes denote concurrent cooling in the biogenic silica record and the haemitite stained grains record. E, accumulation rate data from GISP2 (metre ice/year) (Alley et al., 1997) shown with a 100-year running mean. The data is further applied with an 800-year running mean. F, $\delta^{18} \mathrm{O}$ (SMOW) from DYE-3 (Johnsen et al., 2001) shown with an 80-year running mean. The data is further applied with an 800-year running mean 


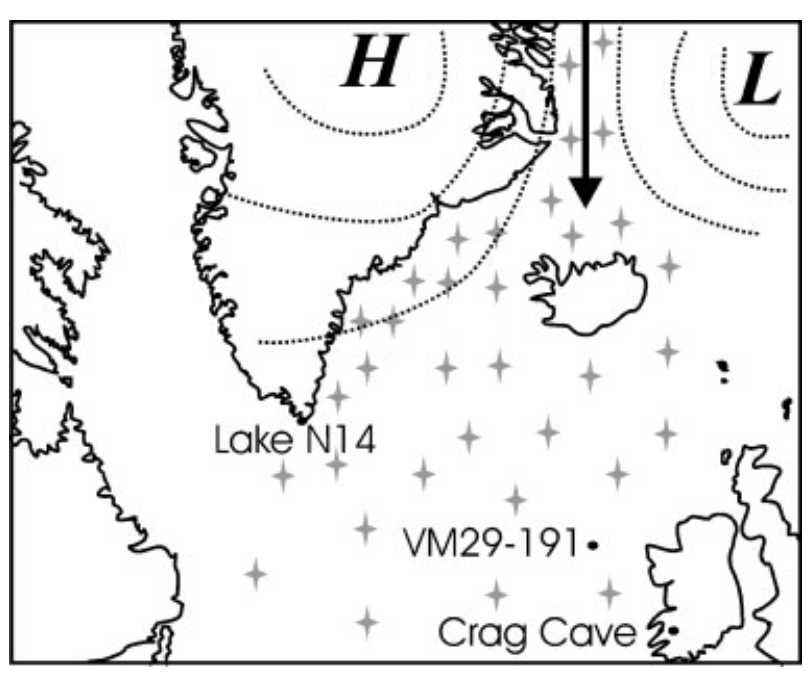

Figure 7 Synoptic presentation of hypothesised atmospheric pressure distribution and associated northern winds and sea-ice distribution (stars) during Holocene cool intervals. Also shown is location of VM29-191 (Bond et al., 2001) and the CC3 speleothem record from Crag Cave in southwestern Ireland (McDermott et al., 2001)

variability on a centennial time scale in the North Atlantic region, this could be related to changes in the atmospheric pressure field. Some of the mismatches in coherence between the two records could then be related to chronological errors. We hypothesize that, during the Holocene, precipitation in southern Greenland was related to the interaction between the Icelandic low pressure and a stable atmospheric high-pressure cell situated over Greenland; when the position of the Icelandic low pressure was closer to Iceland and southern Greenland precipitation was high and the air warmed up in southern Greenland. Although the cause and effect relationship is unknown, a northeastern shift of the low pressure into the Barents Sea region is linked to an extension of the high-pressure cell over Greenland (Fig. 7). This resulted in a drier and colder climate in southern Greenland with increased storm activity. Furthermore, prevailing northerly wind directions in the Greenland Sea increased the strength of the EGC carrying more sea-ice and icebergs to southern Greenland. This explains the climatic teleconnection on a centennial time scale between southern Greenland and the drift ice record in the northeastern Atlantic.

The ideas above are informed by the climatic scenario observed during the 'Great Salinity Anomaly' (GSA) in the 1960s and 1970s. During this period an increased amount of multi-year pack ice left the Arctic Ocean via the EGC and reached the northern coast of Iceland and was further transported with the West Greenland Current to the Labrador Sea and Newfoundland. The water mass returned to the Norwegian Sea via the Faroe-Shetland Channel as a major negative anomaly in surface water salinity and temperature (Dickson et al., 1975; Dickson and Lamb, 1976). It has been suggested that the GSA was related to persistent wind anomalies associated with sea-level pressure anomalies in the Greenland Sea and the Arctic Ocean (Dickson et al., 1988; Walsh and Chapman, 1990). A strong Barents low favoured extension of the stable high-pressure cell over Greenland. As a result winds in the Greenland Sea became northerly and strong, which in turn allowed the pack ice to extend south into the North Atlantic (Björnsson, 1969). Bond et al. (2001) also suggested that episodic cooler climate during the Holocene may be related to conditions resembling those during the GSA, but in a more extreme manner.
It has been debated whether Holocene climate variability on a centennial time scale in the North Atlantic region represents long time scale modulations of the North Atlantic Oscillation (Black et al., 1999; Keigwin and Pickart, 1999; deMenocal et al., 2000; Nesje et al., 2000; Bond et al. 2001; Schulz and Paul, 2002; Noren et al., 2002; Risebrobakken et al., 2003; Dawson et al., 2003). The NAO dipole anomaly pattern should then be reflected by an anti-phase relationship in temperature between western and eastern regions of the North Atlantic Ocean. The in-phase climate relationship between our southern Greenland record and the drift ice record from the Northeastern Atlantic Ocean does not clarify this question, as the drift ice record is related to climate processes occurring in the western Atlantic Ocean. However, a comparison of the southern Greenland record with the CC3 record from southwest Ireland, which infers temperature on the basis of $\delta^{18} \mathrm{O}$ values in speleothem (McDermott et al., 2001), shows that some of the cold and warm periods in the two records concur (Fig. 6B). Notably event a, e, f, g, h, the Dark Ages Cold Period (DACP) as well as the culminations of the Roman Warm Period (RWP) and the Medieval Warm Period (MWP) correlate fairly well with the Lake N14 record, whereas there is no correspondence between the two records between 4000 and $2500 \mathrm{cal}$. yr BP. This implies that southwestern Greenland and the eastern region of the North Atlantic Ocean were climatically in phase on a centennial time scale during parts of the Holocene. The lack of correspondence between the two records in 4000-2500 cal. yr BP could either be related to local effects influencing the respective proxy records or imply that a different climatic scenario than that suggested above dominated in the eastern North Atlantic Ocean at this time.

\section{Conclusions}

Lake sediments from southernmost Greenland record Holocene variability in precipitation. It has been argued that increased input of minerogenic material and biogenic silica reflect increased precipitation while increased growth of moss indicates arid conditions. By assuming that past periods of increased precipitation are linked to proximity of low pressure systems, by inference they must be accompanied by increased temperatures. This is supported by the observed variability in carbon isotope content in radiocarbon-dated material.

The following Holocene climate development is inferred. The earliest Holocene was characterised by a change from moss-dominated sediments to increased minerogenic input and biogenic silica production. This is interpreted to record increased warming and precipitation. However, this trend is superimposed by highly fluctuating short-scale climate events. From 9300 cal. yr BP a more stable climatic regime started. Stabilisation of the surrounding soils decreased input to the lake, which in return decreased aquatic productivity. Generally high levels of precipitation, as indicated by overall high minerogenic input and biogenic silica production, suggest Holocene climatic optimum conditions between 8000 and 5000 cal. yr BP. Around 4700 cal. yr BP increasing sedimentation rate and highly variable moss content are interpreted as the earliest signs of colder conditions (Neoglaciation) with inferred increased proximity of the low pressure system, marking a major reorganisation of the atmospheric circulatory pattern. From $3700 \mathrm{cal}$. yr BP moss content is generally higher and input of minerogenic material and biogenic silica production is generally lower and this is interpreted as a change towards more dry and cold conditions. Furthermore, centennial 
climatic changes increase in amplitude; especially the periods $3700-2400$ cal. yr BP and 1800-600 cal. yr BP are characterised by dry conditions. Increases in content of sulphur are interpreted as the result of storm-related enhanced sea salt spray. In particular the intervals 9300-8000 cal. yr BP, 5700$4000 \mathrm{cal}$.yr BP and $1200-600 \mathrm{cal}$.yr BP are characterised by increased storminess.

The following scenario is inferred to explain the climate variability: when the position of the Icelandic low pressure is closer to Iceland and southern Greenland, climatic conditions in southern Greenland are characterised by relatively high temperatures and increased precipitation. A shift of the low pressure into the Barents Sea area linked with an extension of the high-pressure cell over Greenland causes climate in southern Greenland to become more dry and cold and storminess increases. Furthermore, prevailing northerly wind directions in the Greenland Sea will increase the magnitude of the EGC carrying more sea-ice and icebergs to southern Greenland.

A comparison of the South Greenland record with two palaeoclimate records from the eastern region of the North Atlantic Ocean indicates that a prospective wind-associated drifting of ice may have influenced climate in large parts of the North Atlantic region during certain times of the Holocene.

Acknowledgements This study is part of Camilla S. Andresen's PhD thesis (University of Copenhagen). We would like to thank Dan Conley (DMU) for providing laboratory facilities for biogenic silica analyses. Our two reviewers Dan Charman and Svend Funder are thanked for comments on the manuscript. Accelerator mass spectrometry (AMS) ${ }^{14} \mathrm{C}$ dating was done at the Intitute of Physics and Astronomy (University of Aarhus) by Jan Heienemeier and the dating was paid for by Carlsberg Foundation grant no. ANS.990271/10-1187 to Svante Björck, for which we are very grateful.

\section{References}

Alley RB, Shuman CA, Meese DA, Gow AJ, Taylor KC, Cuffey KM, Fitzpatrick JJ, Grootes PM, Zielinski GA, Ram M, Spinelli G, Elder BC. 1997. Visual-stratigraphic dating of the GISP2 ice core: basis, reproducibility, and application. Journal of Geophysical Research 102: $26367-26381$.

Andresen CS, Bond G, Kuijpers A, Knutz P, Björck S. Holocene climate variability at multidecadal time-scales detected by sedimentological indicators in a shelf core NW off Iceland. Submitted to Marine Geology.

Barber DC, Dyke A, Hillaire-Marcel C, Jennings AE, Andrews JT, Kerwin MW, Bilodeau G, McNeely R, Southon J, Morehead MD, Gagnon J-M. 1999. Forcing of the cold event of 8200 years ago by catastrophic drainage of Laurentide lakes. Nature 400: 344-348.

Bennike O, Björck S. 2000. Lake sediment coring in South Greenland in 1999. Geology of Greenland Survey Bulletin 186: 60-64.

Bennike O, Björck S. 2002. Chronology of the last recession of the Greenland Ice Sheet. Journal of Quaternary Science 17(3): 211-219.

Bennike O, Björck S, Lambeck K. 2002. Estimates of South Greenland late-glacial ice limits from a new relative sea level curve. Earth and Planetary Science Letters 197: 171-186.

Bennion H, Juggins S, Anderson NJ. 1996. Predicting epilimnetic phosphorous concentrations using an improved diatom-based transfer function and its application to lake eutrophication management. Environmental Science and Technology 30: 2004-2007.

Berner RA, Raiswell R. 1984. C/S method for distinguishing freshwater from marine sedimentary rocks. Geology 12: 365-368.

Björck S, Rundgren M, Ingolfsson O, Funder S. 1997. The Preboreal Oscillation around the Nordic Seas: terrestrial and lacustrine responses. Journal of Quaternary Science 12(6): 455-465.

Björck S, Muscheler R, Kromer B, Andresen CS, Heinemeier J, Johnsen SJ, Conley D, Koc N, Spurk M, Veski S. 2001. High-resolution analyses of an early Holocene climate event may imply decreased solar forcing as an important climate trigger. Geology 29: 11071110.

Björck S, Bennike O, Rosén P, Andresen CS, Bohncke S, Kaas E, Conley D. 2002. Anomalously mild Younger Dryas summer conditions in southern Greenland. Geology 30: 427-430.

Björnsson H. 1969. Sea ice conditions and the atmospheric circulation North of Iceland. Jökull 19: 11-17.

Black DE, Peterson LC, Overpeck JT, Kaplan A, Evans MN, Kashgarian M. 1999. Eight centuries of North Atlantic Ocean atmosphere variability. Science 286: 1709-1713.

Bond G, Kromer B, Beer J, Muscheler R, Evans MN, Showers W, Hoffmann S, Lotti-Bond R, Hajdas I, Bonani G. 2001. Persistent solar influence on North Atlantic climate during the Holocene. Science 294: 2130-2136.

Cappelen J, Jørgensen PV, Laursen EV, Stanius LS, Thomsen RS. 2001. The observed climate of Greenland, 1958-99-with climatological standard normals, 1961-90. Technical Report 00-18, Danish Meteorological Institute; 154 pp.

Conley D. 1988. Biogenic silica as an estimate of silicious microfossil abundance in Great Lakes sediments. Biogeochemistry 6: 161-179.

Conley D. 1998. An interlaboratory comparison for the measurement of silica in the marine environment. Marine Chemistry 63: 39-48.

Conley DJ, Schelske CL. 2001. Biogenic silica. In Tracking Environmental Change Using Lake Sediments: Biological Methods and Indicators, Smol JP, Birks HJB, Last WM (eds). Kluwer: Dordrecht; 281-293.

Dansgaard W, Johnsen SJ, Clausen HB, Dahl-Jensen D, Gundestrup NS, Hammer CU, Hvidberg CS, Steffensen JP, Sveinbjørnsdottir $A E$, Jouzel J, Bond G. 1993. Evidence for general instability of past climate from a 250-kyr ice-core record. Nature 364: 218-220.

Dawson AG, Elliott L, Mayewski PA, Lockett P, Noone S, Hickey K, Holt T, Wadhams P, Foster I. 2003. Late-Holocene North Atlantic climate 'seesaws', storminess changes and Greenland ice sheet (GISP2) palaeoclimates. The Holocene 13: 381-392.

Deines P. 1980. The isotopic composition of reduced organic carbon. In Handbook of Environmental Isotope Geochemistry: The Terrestrial Environment, Vol. 1A, Fritz P, Frontes JC (eds). Elsevier: Amsterdam; 329-406.

DeMaster DJ. 1979. The marine budgets of silica and ${ }^{32}$ Si. PhD thesis, Yale University; $308 \mathrm{p}$.

DeMaster DJ. 1991. Measuring biogenic silica in marine sediments and suspended matter. In Marine Particles: Analysis and Characterization, Hurd DC, Spenser DW (eds). American Geophysical Union: Geophysical Monograph 63. Washington, DC; 363-367.

deMenocal P, Ortiz J, Guilderson T, Sarnthein M. 2000. Coherent highand low-latitude climate variability during the Holocene warm period. Science 288: 2198-2202.

Dickson RR, Lamb HH. 1976. A review of recent hydrometeorological event in the North Atlantic sector. ICNAF Special Publication 8: $35-62$.

Dickson RR, Lamb HH, Malmberg SA, Colebrook JM. 1975. Climatic reversal in northern North Atlantic. Nature 256: 479-482.

Dickson RR, Meincke J, Malmberg S-A, Lee AJ. 1988. The 'Great Salinity Anomaly' in the northern North Atlantic, 1968-1982. Progress in Oceanography 20: 103-151.

Dietrich G, Kalle K, Krauss W, Siedler G. 1980. General Oceanography. Wiley: Chichester; 626.

Fredskild B. 1973. Studies in the vegetational history of Greenland. Palaeobotanical investigations of some Holocene lake and bog deposits. Meddelelser om Grønland 198(4): 245.

Funder S, Fredskild B. 1989. Paleofaunas and Floras (Greenland). In Quaternary Geology of Canada and Greenland, Foulton RJ (ed.). Geological Survey of Canada: Toronto; 775-783.

Hanna E, Cappelen J. 2003. Recent cooling in coastal southern Greenland and relation with the North Atlantic Oscillation. Geophysical Research Letters 30: 1132-1134.

Hecky RE, Hesslein RH. 1995. Contributions of benthic algae to lake food webs as revealed by stable isotope analysis. Journal of North American Benthological Society 14: 631-653.

Hughes MK, Diaz HF. 1994. The Medieval Warm Period. Climatic Change 2-3: 109-342.

Hurrell JW. 1995. Decadal trends in the North Atlantic Oscillation: regional temperature and precipitation. Nature 269: 676-679. 
Johnsen S, Dahl-Jensen D, Gundestrup N, Steffensen JP, Clausen HB, Masson-Delmotte V, Sveinbjörnsdottir AE, White J. 2001. Oxygen isotope and palaeotemperature records from six Greenland ice-core stations: Camp Century, DYE-3, GRIP, GISP2, Renland and NorthGRIP. Journal of Quaternary Science 16(4): 299-307.

Kaplan MR, Wolfe AP, Miller GH. 2002. Holocene environmental variability in southern Greenlan inferred from lake sediments. Quaternary Research 58: 149-159.

Kasper JN, Allard M. 2001. Late Holocene climatic changes as detected by the growth and decay of ice wedges on the southern shore of Hudson Strait, Northern Québec, Canada. The Holocene 11: 563-577.

Keeley JE, Sandquist DR. 1992. Carbon: freshwater plants. Plant Cell Environment 15: 1021-1035.

Keigwin LD, Pickart RS. 1999. Slope water current over the Laurentian Fan on interannual to millennial timescales. Science 286: 520-523.

Koc N, Jansen E, Haflidason H. 1993. Paleoceanographic reconstructions of surface conditions in the Greenland, Iceland and Norwegian Seas through the last $14 \mathrm{ka}$ based on diatoms. Quaternary Science Reviews 12: 115-140.

Lassen SJ, Kuijpers A, Kunzendorf H, Hoffmann-Wieck G, Mikkelsen N, Konradi P. 2004. Late Holocene Atlantic bottom water variability in Igaliku Fjord, South Greenland, reconstructed from foraminifera faunas. The Holocene 14(2): 165-171.

Malmberg S-A. 1970. Hafís fyrir Vestfjördum í lok apríl 1969 og straummæling í Látraröst. (Drift ice off NW Iceland in late April 1969. In Icelandic with English summary.) Náttúrufroedingurinn 39: $243-250$.

McDermott F, Mattey DP, Hawkesworth C. 2001. Centennial-scale Holocene climate variability revealed by a high-resolution speleothem $\delta^{18} \mathrm{O}$ record from SW Ireland. Science 294: 1328-1331.

Neff U, Nurns SJ, Mangini A, Mudelsee M, Fleitmann D, Matter A. 2001. Strong coherency between solar variability and the monsoon in Oman between 9 and 6 kyr ago. Nature 411: 290-293.

Nesje A, Lie Ø, Dahl SO. 2000. Is the North Atlantic Oscillation reflected in Scandinavian glacier mass balance records? Journal of Quaternary Science 15: 587-601.

Noren AJ, Bierman PR, Steig EJ, Lini A, Southon J. 2002. Millennialscale storminess variability in the northeastern united States during the Holocene epoch. Nature 419: 821-824.

O'Brien S, Mayewski PA, Meeker LD, Meese DA, Twickler MS, Whitlow SI. 1995. Complexity of Holocene climate as reconstructed from a Greenland ice core. Science 270: 1962-1964.
Osmond CB, Valaane N, Haslam SM, Uotila P, Roksandic Z. 1981. Comparisons of $\delta^{13} \mathrm{C}$ values in leaves of aquatic macrophytes from different habitats in Britain and Finland; some implications for photosynthetic processes in aquatic plants. Oecologia (Berlin) 50: 117-124.

Rau G. 1978. Carbon-13 depletion in a subalpine lake: carbon flow implications. Science 201: 901-902.

Riis T, Sand-Jensen K. 1997. Growth reconstruction and photosynthesis of aquatic mosses: influence of light, temperature and carbon dioxide at depth. Journal of Ecology 85: 359-372.

Risebrobakken B, Jansen E, Andersson C, Mjelde E, Hevrøy K. 2003. A high-resolution study of Holocene paleoclimatic and paleoceanographic changes in the Nordic Seas. Paleoceanography 18(1): 1017. Roncaglia L, Kuijpers A. 2004. Palynofacies analysis and organicwalled dinoflagellate cysts in late Holocene sediments from Igaliku fjord, South Greenland. The Holocene 14(2): 172-184

Ryves DB, McGowan S, Anderson NJ. 2002. Development and evaluation of a diatom-conductivity model from lakes in West Greenland. Freshwater Biology 47: 995-1014.

Schulz M, Paul A. 2002. Holocene climate variability on centennial-tomillennial time scales: 1 . Climate records from the North Atlantic realm. In Climate Development and Hisotry of the North Atlantic Realm, Wefer G, Berger WH, Behre K-E, Jansen E (eds). Springer Verlag: Berlin; 41-54.

Sigtryggsson H. 1972. An outline of sea ice conditions in the vicinity of Iceland. Jökull 22: 1-11.

Stuiver M, Reimer P. 1993. Radiocarbon calibration program Rev. 3.3.3A-Mac Test Version \#6. Radiocarbon 35: 215-230.

Stuiver M, Reimer P, Bard E, Beck JW, Hughen KA, Kromer B, McCormack FG, vand en Plicht K, Spurk M. 1998. INTCAL98 radiocarbon age calibration 24000-0 cal B.P. Radiocarbon 40: 1041-1083.

Taylor KC, Lamorey GW, Doyle GA, Alley RB, Grootes PM, Mayewski PA, White JWC, Barlow LK. 1993. The 'flickering switch' of late Pleistocene climate change. Nature 361: 432-436.

ter Braak CJF, Smilauer P. 1998. Canoco for Windows. Centre for Biometry: Wageningen.

Walsh JE, Chapman WL. 1990. Arctic contribution to upper-ocean variability in the North Atlantic. Journal of Climate 3(12): 14621473.

Willemse NW, Törnqvist TE. 1999. Holocene century-scale temperature variability from West Greenland lake records. Geology 27(7): 580-584. 